\title{
The Case for Ending Migration Controls
}

\section{Nick Megoran}

School of Geography, Politics and Sociology, University of Newcastle upon Tyne,

Newcastle upon Tyne NE1 7RU http://www.megoran.org

With a general election looming in Britain, early 2005 witnessed the ugly - if far from unprecedented-re-appearance of immigration as a crucial battleground in domestic political contest (see, for example, Travis and White 2005). The opposition Conservative Party (quite wrongly) accused the Labour government of allowing "unlimited" immigration into Britain. Panicked, Labour responded by moving to assure the public that they are "tough" on the issue, hastily enshrining this in their election manifesto. Throughout these exchanges, the assumption that the regulation of migration is essential remained unquestioned. However, the case for ending migration controls (both in Britain and in similar advanced capitalist states) is compelling on a number of grounds, and the objections to it dubious (Bauder 2003). It is important that geographers restate the arguments at this time.

\section{The Case for Open Borders}

Historically, migration has always been part of the human experience. The modern capitalist world arose with complex cycles of migrants who moved seasonally to supplement family incomes (Sassen 1999). Formal migration controls were rare, the first modern legislation to restrict immigration to Britain being the Aliens Act, an anti-Jewish measure that appeared only in 1905.

One of the strongest contemporary arguments for ending immigration controls is economic, to obtain workers to do the jobs that existing inhabitants are unable (or unwilling) to undertake. Farming, light manufacture, health provision, and many service sectors of North American and European Union economies would implode if migrants were suddenly spirited away overnight. In the long term, Europe faces a demographic crisis as low birth rates threaten population decline. Without increased immigration, it is doubtful if even a significant rise in the age of retirement could prevent serious disruption to economic and social life. 
It is not only prosperity in the global North that is jeopardised by immigration controls. The transfer of remittances by migrant workers to their homes in the global South is one of the largest flows of finance today. To limit migration is to both slow worldwide growth and to chain people in poverty. As geographer Ronald Skeldon put it, "migration is development" (Skeldon 1997:205).

Quite often, the beneficial effects of migration are difficult to predict. It is not simply that the interaction of different peoples and cultures is enriching in and of itself. King observes that diasporic populations have not uncommonly played crucial rules in democratic state building as countries emerge from totalitarian rule or internal conflict (1998:16). Migration might thus be conceived of as a longterm investment in democracy.

But it is arguably the moral argument against migration controls that is the most compelling. Because of the global economic inequalities cemented by the current practice of migration controls, movement still occurs as workers outwit border guards to move illegally from poorer to richer places. These unregistered migrants are vulnerable to abuse and exploitation. The drowning of 23 Chinese cocklepickers in Morecambe Bay in the UK in 2004, and the suffocation of 58 of their compatriots in a container in Dover in 2000 (en route to work in London restaurants) are but the tip of a terrible iceberg. Every year around 600 Mexicans die at the US border, and untold hundreds perish on the shores of the EU, the victims of new legislative regimes that have been dubbed "the wall around the West" (Andreas 2000). To tolerate such death tolls, whilst simultaneously relying upon the labour of those migrants who do manage to enter illegally, is sheer hypocrisy.

\section{Countering Objections}

The most common objection to ending migration controls is that those countries with higher incomes would be "swamped" by poor migrants. However, migrations are neither random events nor the mass invasion of rich countries by poor people. They are carefully patterned processes that are sensitive to political structures, historical connections (such as colonialism), and economic opportunities. They are commonly cyclical in nature. Thus one-third of overseas migrants to the USA in the early twentieth century eventually returned to their homes; easier and cheaper travel makes migrants even less likely to permanently relocate today. Indeed, in spite of facilitating important temporary migration cycles, and in the face of dire warnings to the contrary, the EU has produced no significant permanent population movements from poorer to richer countries. 
Those on the left have traditionally been concerned that migration would undermine the welfare state. There is no evidence to substantiate this fear. People who migrate are generally young and fit, able and anxious to work, and rarely in need of welfare. Absurdly, current arrangements, by driving migrant workers underground, deprive governments of their potential tax contributions to the welfare state. Nor would the needy "flood" over newly opened boundaries. How many British pensioners, or single mothers, or those unable to work due to illness, migrate to Denmark and claim greater welfare as, legally, they are entitled to? The answer is that they do not, for the same reasons that most Bangladeshis or Peruvians do not want to come to Britain or the USA: the uprooting from familiar contexts is too disruptive.

Another concern commonly voiced, especially since the September 11, 2001 attacks in the USA, is that ending immigration controls will lay receiving states open to flows of drugs, disease, and terrorists. This need not be so. If immigration regulations are abandoned, borders could still be monitored to enforce quarantine restrictions in emergencies and to control contraband. Passports could be checked to apprehend criminals identified by international police co-operation. In fact, decriminalising immigration would actually aid the fight against organised crime. At present, migrants turn to gangs to smuggle them into the EU, creating cultures of violent criminality and unnecessarily diverting police resources to combat a problem that is largely of our own making.

Lastly, proponents of immigration controls cite the need to defend national sovereignty. State sovereignty is, however, a dynamic process. The nation-state has historically had numerous rivals to dispute any claim to absolute sovereignty over territory. Where once these might have been feudal landowners, trading groups such as the Hanseatic League, and the Catholic Church, now they are more likely to be organisations founded by international treaty such as the UN, the EU, and the World Trade Organisation. Sovereignty is a means that must never be confused for the end: the security that arises from justice and peace.

\section{Resisting Migration Controls}

If the case for ending immigration controls is so compelling, why do they exist? Their modern roots can be found in the politicisation of migration by Western states. The 1948 Universal Declaration of Human Rights proclaims the solemn right to move freely within one's own country and to leave it, but there exists no comparable right to enter another country. This absurdity was a cynical swipe at the Communist regimes of Eastern Europe and the Soviet Union. But the background to this year's repoliticisation of immigration in the 
British context is the post-war politics of race. The 1948 Nationality Act confirmed all empire and commonwealth citizens as British. The process of rescinding this began with the Conservatives' 1962 Commonwealth Immigration Act, pandering to prejudice in the right-wing press. Labour denounced it as racist, but upon coming to power in 1964 actually strengthened its provisions. Cabinet member Richard Crossman later admitted that this was because immigration was seen as a potential vote loser. Every subsequent British government, including that of Tony Blair, has played the same game (Dummett 2001: especially chapters 6 and 7).

Yet immigration controls have always been resisted by progressive forces. The 1899 International Emigration Conference in London affirmed the "fundamental liberty" of every individual "to come and go" as they pleased (Harris 2002:131). In the 1980s, the Reagan administration deported asylum seekers fleeing the brutality of USbacked right-wing paramilitary forces and dictators, sending many back to torture and certain death. Outraged, groups of US churches collaborated with their Central American counterparts to set up a covert network that smuggled asylum seekers into the US and concealed them across the country. They drew on the vision and methods of the "underground railroad" that once transported escaped slaves to safety from the southern states (Golden and McConnell 1986). Numerous activist groups have arisen across Europe to campaign for the rights of asylum seekers and undocumented migrant workers (Hayter 2000: chapter 4). The vision of a world of open borders has not been extinguished, although it has rarely been under as much pressure as that exerted in the name of the so-called "war on terror".

Current immigration controls in Britain and other Western states are expensive to administer and cannot possibly achieve their desired effect. They hamper economic growth and perpetuate inequalities, undermine the welfare state, contradict formal commitments to liberal values and human rights, foster criminality, and condemn the vulnerable to exploitation and even death. They are the unfortunate heritage of a reprehensible chapter of twentieth century politics. It is imperative that geographers, with their sensitivity to complex histories of space, flows, exclusion, and the politics of identity, play a part in the struggles to close that chapter by ending immigration controls.

\section{References}

Andreas P (2000) The Wall Around the West: State Borders and Immigration Controls in North America and Europe. Oxford: Rowman and Littlefield

Bauder H (2003) Equality, justice and the problem of international borders: The case of Canadian immigration regulation. ACME: An International E-Journal for Critical Geographies 2:167-182. http://www.acme-journal.org/

Dummett M (2001) On Immigration and Refugees. London: Routledge 
Golden R and McConnell M (1986) Sanctuary: The New Underground Railroad. New York: Orbis

Harris N (2002) Thinking the Unthinkable: The Immigration Myth Exposed. London: I B Tauris

Hayter T (2000) Open Borders: The Case Against Immigration Controls. London: Pluto King C (1998) Introduction: Nationalism, transnationalism, and postcommunism. In $\mathrm{C}$ King and N Melvin (eds) Nations Abroad: Diaspora Politics and International Relations in the Former Soviet Union (pp 1-25). Oxford: Westview

Sassen S (1999) Guests and Aliens. New York: New Press

Skeldon R (1997) Migration and Development: A Global Perspective. Harlow: AddisonWesley Longman

Travis A and White M (2005) Clarke aims to steal Tories' thunder with tough immigration package. The Guardian 7 February. http://www.guardian.co.uk (last accessed 1 March 2005). 